\title{
Assessment of functional status in the ICU: instruments used in Brazilian settings
}

\author{
Avaliação da funcionalidade em UTI: instrumentos \\ usados no cenário brasileiro
}

Luiza Martins Faria, Sayonara de Fátima Faria Barbosa*

Universidade Federal de Santa Catarina (UFSC), Florianópolis, SC, Brazil

\begin{abstract}
Introduction: Physical function impairment is a significant concern for patients who survive their intensive care unit (ICU) stay, due to its impact on the patient's independence and functional status. In this context, the choice of a suitable instrument for the assessing functional status is important, because an inappropriate assessment could lead to incorrect conclusions regarding patient prognosis, treatment benefits, and condition. Objective: To identify which functional assessment tools are used in Brazil to assess patients who are in ICU. Additionally, we investigated the translation, adaptation, and validation of these instruments for use in this population. Methods: We searched Pubmed, SCIELO, Lilacs, and Scopus in November 2015. No language or date restrictions were applied to the search. Results: Ten studies and seven instruments were identified. The most commonly used instruments were the Karnofsky Performance Status Scale Scores and the Functional Independence Measure. Conclusion: The instruments found in the review were neither specifically developed to assess the functional status of ICU patients, nor were they validated for use in this population in Brazil. Transcultural development or adaptation studies should be conducted, followed by a validation process.
\end{abstract}

Keywords: Intensive Care Units. Activities of Daily Living. Outcome and Process Assessment. Rehabilitation.

Resumo

Introdução: O comprometimento da função física é um aspecto significativo em pacientes que sobrevivem à internação em UTI, considerando o impacto na independência e funcionalidade desses indivíduos. Dentro deste contexto, a escolha de um instrumento adequado para avaliação da funcionalidade é de grande importância, pois uma avaliação inapropriada pode gerar conclusões incorretas em relação à condição do paciente,

* LMF: Doctoral Student, e-mail: lumartinsfaria@yahoo.com.br SFFB: PhD, e-mail: sayonara.barbosa@ufsc.br 
prognóstico e benefícios do tratamento. Objetivo: Identificar os instrumentos utilizados no Brasil para avaliação da funcionalidade de pacientes internados em UTI e a tradução, adaptação e validação destes instrumentos para essa população. Métodos: A busca dos artigos foi realizada a partir das bases de dados Pubmed, SCIELO, LILACS e SCOPUS, em novembro de 2015, sem restrição de data ou idioma. Resultados: Foram identificados dez estudos e sete instrumentos, sendo que os mais utilizados foram o Karnofsky Performance Status Scale Scores e a Medida de Independência Funcional. Conclusão: Os instrumentos identificados não foram desenvolvidos especificamente para a avaliação da funcionalidade de pacientes internados em UTI e não foram submetidos ao processo de validação para população brasileira internada nesta unidade. Sugerem-se estudos de construção ou adaptação transcultural, seguidas do processo de validação, de instrumentos de avaliação da funcionalidade de pacientes internados em UTI para aplicação no cenário brasileiro.

Palavras-chave: Unidades de Terapia Intensiva. Atividades Cotidianas. Avaliação de Processos e Resultados. Reabilitação.

\section{Introduction}

Technical and scientific advances in the intensive care field have led to a significant increase in the survival rate of critically ill patients, resulting in increased exposure time of these patients to etiological factors for the development of muscle weakness and neuromuscular dysfunction, with direct impact on physical function, quality of life after hospital discharge $(1,2)$, and the occurrence of neuropsychological complications (3). For patients hospitalized in the intensive care unit (ICU), surviving the critical illness that led to hospitalization is only the beginning of a long and arduous journey of physical and psychological rehabilitation (4). Therefore, there is a growing need to explore and understand the aspects related to morbidity after discharge and the rehabilitation process of these patients $(5,6)$, in order to make an early identification of the patient's future condition and minimize the consequences of hospitalization in the ICU, which can vary according to the primary ICU admission cause, the onset of complications, and the length of stay in this unit.

According to the International Classification of Functioning, Disability and Health (ICF), functioning should be considered in a biopsychosocial model and encompasses all body functions (physiological functions and body structure), activities (performance of a task or action by an individual), and participation (an individual's involvement in a real-life situation) (7). Within this context, a prolonged ICU stay negatively affects physical functioning because it leads to numerous consequences for the physical and psychological capacity of patients, in addition to the social and economic impacts to the individual and his/her family (8). This has a negative influence on the patients' quality of life and can persist for years after discharge from the ICU $(5,9,10)$.

For this reason, the functional status of patients admitted to the ICU is has become an increasingly studied topic, especially due to its impact on prognosis after ICU and hospital discharge (11).

Not being capable of accomplishing basic tasks of everyday life has a direct impact on an individual's quality of life. Thus, the use of tests and assessment scales to determine a patient's functional profile and establish an adequate therapeutic intervention is of paramount importance (12). In addition, the characterization of the functional status of critically ill patients prior to their ICU admission as well as their medical history is critical in the development of an appropriate physical therapy plan (1). In this context, the choice of a suitable instrument is important, because an inappropriate assessment could lead to incorrect conclusions regarding patient prognosis, treatment benefits, and condition (13).

Given the impact of ICU admission on patients' functional status and the importance of quality assessment tools, this study aimed to identify which functional assessment tools are used in Brazil to assess patients who are in ICU, and to investigate the translation, adaptation, and validation of these instruments for use in this population.

\section{Methods}

This integrative review was performed in accordance with the guidelines by Ganong (14). The following methodological steps were undertaken: definition of inclusion and exclusion criteria; definition of the information to be extracted from selected studies; studies 
categorization; data analysis and interpretation; evaluation of the outcomes, and review/knowledge synthesis presentation (14). We searched Pubmed, SCIELO, LILACS, and SCOPUS in November 2015, using a combination of the following keywords: funciona*; function*, UTI, terapia intensiva, cuidado Intensivo, cuidados intensivos, cuidado critico, cuidados criticos, paciente critico, pacientes criticos, "intensive therapy", "intensive care", "critical care", "critical ill", "critical illness", Brazil*. We also used truncation $\left({ }^{*}\right)$ in order to retrieve the largest possible number of relevant references associated with the term searched or with variations of its concept. The search strategy is shown in Table 1.

Table 1 - Search strategy

\begin{tabular}{|c|c|c|}
\hline Database & Search strategy & $\begin{array}{l}\text { Number } \\
\text { of papers }\end{array}$ \\
\hline Scielo & $\begin{array}{l}\text { (funciona* OR function*) AND (UTI OR } \\
\text { terapia intensiva OR cuidado Intensivo } \\
\text { OR cuidados intensivos OR cuidado } \\
\text { critico OR cuidados criticos OR } \\
\text { paciente critico OR pacientes criticos } \\
\text { OR "intensive therapy" OR "intensive } \\
\text { care" OR "critical care" OR "critical ill" } \\
\text { OR "critical illness") }\end{array}$ & 587 \\
\hline LILACS & $\begin{array}{l}\text { tw:((funciona* OR function*) AND } \\
\text { (uti OR terapia intensiva OR cuidado } \\
\text { Intensivo OR cuidados intensivos OR } \\
\text { cuidado critico OR cuidados criticos } \\
\text { OR paciente critico OR pacientes } \\
\text { criticos OR "intensive therapy" OR } \\
\text { "intensive care" OR "critical care" } \\
\text { OR "critical ill" OR "critical illness")) } \\
\text { AND (instance: regional) AND } \\
\text { (db:("LILACS")) }\end{array}$ & 1,043 \\
\hline Pubmed & $\begin{array}{l}\text { function* AND ("intensive therapy" OR } \\
\text { "intensive care" OR "critical care" OR } \\
\text { "critical ill" OR "critical illness") AND } \\
\text { brazil* }\end{array}$ & 264 \\
\hline SCOPUS & $\begin{array}{l}\text { TITLE-ABS-KEY(function* AND } \\
\text { ("intensive therapy" OR "intensive care" } \\
\text { OR "critical care" OR "critical ill" OR } \\
\text { "critical illness") AND brazil*) }\end{array}$ & 75 \\
\hline
\end{tabular}

Source: Authors.

No filters were applied to the search. Search terms could occur anywhere in the article. Only articles published in full manuscript form were considered. No date or language limits were placed on the results.
A manual search of references from retrieved articles was also performed, and other studies were used to support discussions relevant to the study topic.

Inclusion criteria were: target population consisting of adult ICU patients; studies conducted in Brazil; having the assessment of functional status of ICU patients clearly identified in the study objectives; use of some kind of functional assessment method; reporting randomized clinical trials, quasi-experimental studies or observational studies or else describing the development of a tool for assessing functional status in ICU patients.

The following information was used to characterize the articles: tool used, sample, study design and time of assessment.

\section{Results}

The search identified 1,969 papers. After reading the titles and the abstracts, 36 potentially eligible articles retained. After reading the full manuscript, taking into account the study objectives, and applying the inclusion criteria, 23 studies were selected. After excluding all duplicate articles, 10 studies were included in this review. Figure 1 shows a flowchart of the studies selection process:

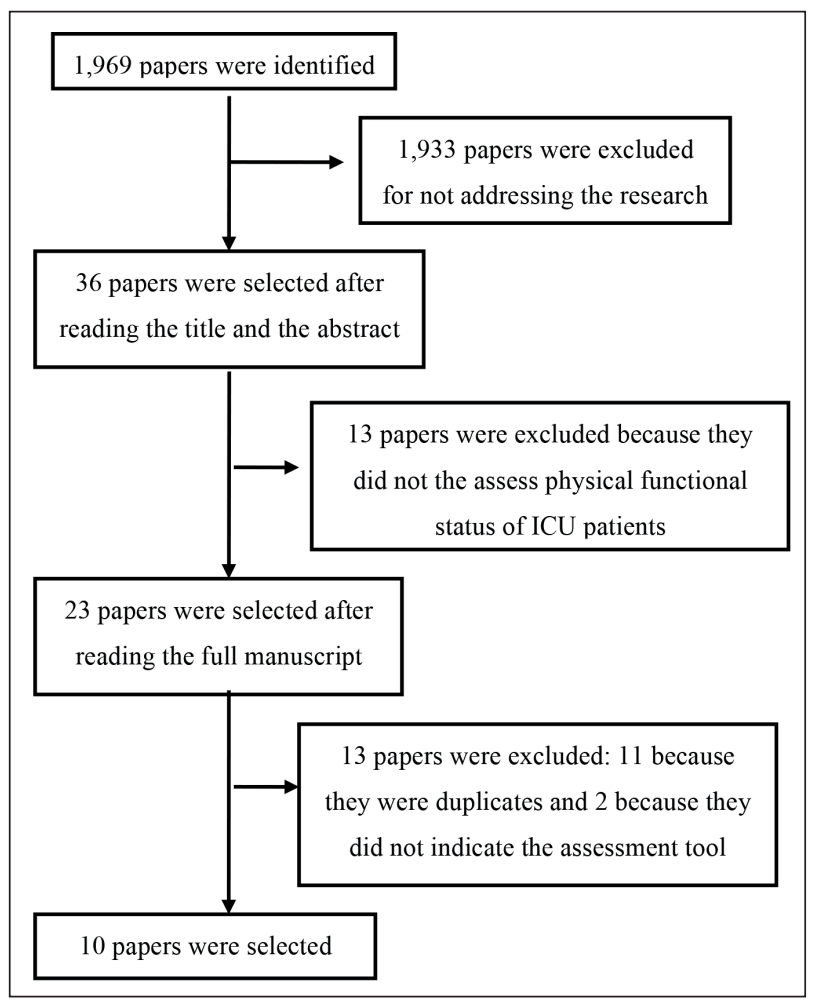

Figure 1 - Studies selection process. 
According to the literature, the following tools are used to assess the physical functional status of ICU patients in Brazil: the Barthel scale (15), Karnofsky Performance Status Scale Scores $(15,16,17,18)$, Functional Independence Measure (FIM) $(19,20)$, Lawton Instrumental Activities of Daily Living (IADL) Scale (16), Eastern Cooperative Oncology Group Scale $(21,22)$, the extended version of the Glasgow Outcome Scale (23), and a scale developed by Muramaki et al. (24).

\section{Discussion}

Seven instruments were identified, the most commonly used being the Karnofsky Performance Status Scale Scores and the Functional Independence Measure. Table 2 illustrates the characteristics of the studies included in this review.

Table 2 - Characteristics of the studies included in this review

\begin{tabular}{|c|c|c|c|c|}
\hline Authors & $(\mathrm{N})$ & Study design & Assessment tool & Time of assessment \\
\hline Murakami et al. 2015 & 463 & $\begin{array}{l}\text { Retrospective cross- } \\
\text { sectional }\end{array}$ & Authors' own scale & Daily until ICU discharge \\
\hline Azevedo et al., 2014 & 717 & Observational & $\begin{array}{l}\text { Eastern Cooperative Oncology Group } \\
\text { scale }\end{array}$ & $\begin{array}{l}\text { First } 48 \text { hours after ICU } \\
\text { admission }\end{array}$ \\
\hline Vesz et al., 2013 & 79 & Observational & $\begin{array}{l}\text { Barthel scale and Karnofsky } \\
\text { Performance Status Scale Scores }\end{array}$ & $\begin{array}{l}\text { First week after ICU } \\
\text { discharge }\end{array}$ \\
\hline Haas et al., 2013 & 499 & Observational & $\begin{array}{l}\text { Karnofsky Performance Status Scale } \\
\text { Scores and Lawton Instrumental } \\
\text { Activities of Daily Living (IADL) Scale }\end{array}$ & $\begin{array}{l}\text { On ICU admission and } 24 \\
\text { hours after discharge }\end{array}$ \\
\hline Reis et al., 2013 & 311 & Observational & $\begin{array}{l}\text { Extended version of the Glasgow } \\
\text { Outcome Scale }\end{array}$ & At hospital discharge \\
\hline Curzel, et al., 2013 & 44 & Observational & FIM & $\begin{array}{l}\text { Pre-admission report } \\
\text { and first week after ICU } \\
\text { discharge }\end{array}$ \\
\hline Garcia et al., 2012 & 77 & Observational & FIM & $\begin{array}{l}\text { Before ICU admission and } 7 \text {, } \\
15,30 \text { and } 60 \text { days after ICU } \\
\text { discharge }\end{array}$ \\
\hline Teixeira et al., 2011 & 231 & Observational & $\begin{array}{l}\text { Karnofsky Performance Status Scale } \\
\text { Scores }\end{array}$ & $\begin{array}{l}\text { Pre-admission report and } \\
\text { two years after discharge }\end{array}$ \\
\hline Soares et al., 2010 & 717 & Observational & $\begin{array}{l}\text { Eastern Cooperative Oncology Group } \\
\text { scale }\end{array}$ & $\begin{array}{l}\text { First } 48 \text { hours after ICU } \\
\text { admission }\end{array}$ \\
\hline Cabral et al., 2009 & 100 & Observational & $\begin{array}{l}\text { Karnofsky Performance Status Scale } \\
\text { Scores }\end{array}$ & $\begin{array}{l}\text { Pre-admission report and } \\
\text { post-discharge assessment }\end{array}$ \\
\hline
\end{tabular}

Note: $(\mathrm{N})=$ sample; FIM = Functional Independence Measure; ICU = Intensive Care Unit. 
The study that used the Barthel scale to assess the functional status of patients immediately after ICU discharge (first week after discharge) (15), indicated that the researchers had been trained to administer the tool, how the scale assesses functional status and that it has already been translated into Brazilian Portuguese. The assessment performed using the Barthel scale revealed that patients had a reduced functional status and an increased level of dependency one week after ICU discharge.

The Barthel scale is a tool largely used to assess functional independence and mobility. The scale measures an individual's ability to perform 10 basic activities of daily living. These are divided into selfcare activities (such as eating, bathing, dressing, grooming, bowels, bladder, toilet use) and mobility (transfers from bed to chair and back, walking and climbing stairs). The scale offers a quantitative estimate of a patient's level of dependency to perform the activities. The total scores range from 0 (totally dependent) to 100 (totally independent) (13), with 0-20 totally dependent; 21 - 61 severely dependent; 62 - 90 moderately dependent; 91 - 99 slightly dependent; 100 totally independent) (25). The Barthel Index (BI) was used to classify patients as having no or minimal disability (BI score >90), moderate dependency (BI score 90 - 55) and severe dependency (BI score < 55) (13) and can be self-completed by the patient or by a family member or caregiver (25).

According to the results of this review, the Karnofsky/Performance Status Scale Scores is the most widely used tool among researchers in Brazil $(15,16,17,18)$. It has been largely used to assess functional status in patients with incapacitating chronic disease, such as critically ill ICU patients. The total scores range from 100 (perfect health) to 0 (death) $(13,15)$. The patient is classified as: 100 - Normal, no complaints, no evidence of disease; 90 - Able to carry on normal activity, minor signs or symptoms; 80 - Normal activity with effort, some signs or symptoms of disease; 70 - Care for self, unable to carry on normal activity or to do active work ; 60 - Requires occasional assistance, but is able to care for most of his needs; 50 - Requires considerable assistance and frequent medical care; 40 - Disabled, requires special care and assistance; 30 Severely disabled, hospitalization is indicated although death not imminent; 20 - Hospitalization necessary, very sick, active supportive treatment necessary; and 10 Moribund, fatal processes progressing rapidly (15). A score between 70 - 100 is usually considered to be a favorable functional status score (13). Only one of the four studies that used this tool described how it assesses functional status and also reported that the researchers who administered it had been previously trained on the use of the scale (15). Two of the aforementioned studies just reported that the researchers had been trained to administer the scale $(16,18)$.

Muramaki et al. assessed the functional evolution of patients subjected to an early rehabilitation protocol during ICU hospitalization. Patients' functional status was assessed using a scale developed by the researchers. The scale was also used to allocate patients to different intervention plans. The intervention plans were divided into: Plan I: bedridden and sedated patients unable to cooperate with the therapy; Plan II: bedridden patients, albeit able to cooperate with the therapy and perform assisted bedside sedestation with minimal support; Plan III: patients able to perform orthostatism and tolerate ambulation training with assistance for limited distances; Plan IV: patients able to walk and tolerate progressive ambulation training. The study showed that patients responded positively to the intervention strategy proposed in the protocol, with improved Intervention Plans upon discharge from the ICU compared to ICU admission (the plan assessed the functional status of patients included in the study) (24).

The FIM was used in two studies to assess patients' functional status $(19,20)$. The tool assesses a person's level of independence in the performance of a series of motor and cognitive activities of daily living. Among the activities assessed are self-care, mobility (transfers), locomotion, sphincter control, communication, and social cognition. Each item is scored from 1 (totally dependent) to 7 (totally independent). The total score ranges from 18 to 126, with higher scores indicating higher levels of functional independence (26). This tool is widely accepted to assess the functional status of ICU patients and to determine a patient's progression during rehabilitation (13). Curzel et al. assessed patients' functional status immediately after ICU discharge (on the day of discharge) and 30 days after ICU discharge (via telephone interview) using the FIM. In their study, the authors described how the tool assesses functional status and reported that all the assessments were performed by the same raters. The authors showed an improvement in the patient's Functional Independence Measure scores within 30 days after ICU discharge (20). Garcia et al. assessed functional status by means of an interview before and 7, 15, 30 and 60 days after ICU discharge. Like the study mentioned above, this study also 
reported how the scale assesses functional status. The results revealed that patients assessed using the FIM had significantly reduced functional independence in most of the periods assessed, showing recovery only on day 60 after discharge (19).

The Lawton Instrumental Activities of Daily Living (IADL) Scale, used by Hass et al. (16), comprises eight items, including physical and cognitive function. The total scores range from 0 (low function) to 8 (high function). The areas of function assessed are: using a telephone, shopping, food preparation, housekeeping, doing laundry, mode of transportation, responsibility for own medications and handling finances (27). The authors reported that raters had been previously trained on the use of the scale, but they did not describe how the scale is used. The results demonstrated a reduction in patients' ability to perform activities of daily living, even 24 months after ICU discharge (16).

The Eastern Cooperative Oncology Group Scale, used by two studies $(21,22)$, is used for a specific population of individuals diagnosed with cancer and assesses patients' functional status with regard to their ability to perform self-care, activities of daily living and physical abilities (e.g., walking, working, etc.). The score for each activity assessed ranges from 0 (totally dependent) to 5 (death). The aforementioned studies revealed that patients with worse functional status, as measured by the Eastern Cooperative Oncology Group Scale, showed worse results with regard to the development of clinical aspects associated with their hospital admission due to cancer $(21,22)$.

Reis et al. used the extended version of the Glasgow Outcome Scale (23), a global measure used to assess functioning outcomes of patients with traumatic brain injury that allows standardized descriptions of a patient's objective degree of recovery. It is composed of 8 categories, with a total score ranging from 1 to 8 points: upper good recovery (8 points), lower good recovery ( 7 points), upper moderate disability ( 6 points), lower moderate disability ( 5 points), upper severe disability (4 points), lower severe disability (3 points), vegetative state ( 2 points) and death (1 point). Its use may guide an early intensive recovery, contributing to achieving a better functional outcome in patients with traumatic brain injury in the first months after injury, thus increasing their chance of returning to work (28). The results of the study revealed that a worse functional status, as assessed by the extended Glasgow
Outcome Scale, was associated with extubation failure in patients with traumatic brain injury (23).

Analyzing the tools used in Brazilian settings according to the ICF approach (7), we found that the assessment of functional status and of disabilities resulting from ICU hospitalization should take into account both the dysfunction presented by the individual and the limitation of activities and restriction in social participation, and environmental factors. Thus, the tool that is closer to this concept is the FIM, which assess daily life activities based on motor aspects, communication and social interaction, taking into consideration the level of assistance provided by persons, devices or environmental changes. However, it does not concretely cover the aspects considered in the ICF.

Of the tools identified in this review, only the Barthel scale (29) and the FIM (26) have been translated into Brazilian Portuguese. Although they have been transculturally adapted for Brazil, none of them has been developed to assess ICU patients or has been validated for use in this population in Brazil. This also holds true for other tools cited in this review. They have not been specifically developed to assess the functional status of ICU patients nor have they been transculturally adapted or validated in Brazil.

The analysis of the studies showed that most of them assessed patients' functional status immediately after ICU discharge or months after ICU hospitalization. The knowledge of factors associated with reduced functional status together with the knowledge of a patient's functional condition during hospitalization is of great importance due to the possibility of intervening on modifiable factors and gear treatment plans according to the patient's current condition and his/ her functional prognosis.

Therefore, Physical Therapy is seen as an integral component in the multidisciplinary management of ICU patients (30). Improved functional status is a clinical outcome that has already been evidenced by a physical therapy program in the ICU (31). A highlight in this context has been ICU early mobilization programs, which are proven feasible, safe and beneficial for patients $(32,33,34)$.

Physical function impairment is a significant aspect in patients who survive intensive care unit (ICU) stay, due to the impact on patient's independence and functional status (4). This compromises the rehabilitation process, affects the recovery of functionality (35), and has social and economic impacts on 
individuals and families (8). In this context, although many different tools are already available for the diagnosis of physical functional status in intensive care units, there is an emerging need for transcultural development or adaptation studies, followed by a methodological validation process for use in Brazilian settings. The choice of a suitable instrument is important, because an inappropriate assessment could lead to incorrect conclusions regarding patient prognosis, treatment benefits, and condition (13).

Moreover, when choosing a tool one should keep in mind that the characterization of the functional status of critically ill patients prior to their ICU admission as well as their medical history is critical in the development of an appropriate physical therapy plan (1), because patients' functional status prior to ICU admission may influence their post-ICU admission functional assessment results (during ICU hospitalization or shortly after ICU admission) as well as their rehabilitation process and functional prognoses.

Although may studies using different tools to assess the functional status of ICU patients have been recently conducted in Brazil, international studies on the development of the original tools $(28,36,37$, $38,39,40$ ), have mostly been conducted a much longer time ago. This raises the question of why these tools are so little used in Brazilian settings when it has already been proved that the identification of factors that may reduce functional using these tools may contribute to their prevention during hospitalization as well as to the promotion of functional capacity after discharge.

A limitation of this study may be the potential noninclusion of studies related to the topic due to the search strategy and databases used. Nevertheless, this is a reality in review studies, even with careful structuring of the methods.

\section{Conclusion}

This review identified which functional assessment tools are used in Brazil to assess the functional status of patients who are in ICU. We found that, although the instruments can be administered to this population, they were neither specifically developed for use in Brazilian ICU patients, nor were they validated for use in this population. Transcultural development or adaptation studies should be conducted, followed by a methodological validation process.

\section{References}

1. França EET, Ferrari F, Fernandes P, Cavalcanti R, Duarte A, Martinez BP, et al. Fisioterapia em pacientes críticos adultos: recomendações do Departamento de Fisioterapia da Associação de Medicina Intensiva Brasileira. Rev Bras Ter Intensiva. 2012;24(1):6-22.

2. van Der Schaaf M, Beelen A, Dongelmans DA, Vroom MB, Nollet F. Poor functional recovery after a critical illness: a longitudinal study. J Rehabil Med. 2009;41(13):1041-8.

3. Tansey CM, Louie M, Loeb M, Gold WL, Muller MP, de Jager J, et al. One-year outcomes and health care utilization in survivors of severe acute respiratory syndrome. Arch Intern Med. 2007;167(12):1312-20.

4. Batt J, Santos CC, Cameron JI, Herridge MS. Intensive Care Unit-acquired Weakness: clinical phenotypes and molecular mechanisms. Am J Respir Crit Care Med. 2013;187(3):238-46.

5. Fan E, Dowdy DW, Colantuoni E, Mendez-Tellez PA, Sevransky JE, Shanholtz C, et al. Physical Complications in Acute Lung Injury Survivors: A 2-Year Longitudinal Prospective Study. Crit Care Med. 2014;42(4):849-59.

6. van Der Schaaf M, Dettling DS, Beelen A, Lucas C, Dongelmans DA, Nollet F. Poor functional status immediately after discharge from an intensive care unit. Disabil Rehabil. 2008;30(23):1812-8.

7. Farias N, Buchalla CM. A Classificação Internacional de Funcionalidade, Incapacidade e Saúde da Organização Mundial da Saúde: Conceitos, Usos e Perspectivas. Rev Bras Epidemiol. 2005;8(2):187-93.

8. Griffiths J, Hatch RA, Bishop J, Morgan K, Jenkinson $\mathrm{C}$, Cuthbertson $\mathrm{BH}$, et al. An exploration of social and economic outcome and associated health-related quality of life after critical illness in general intensive care unit survivors: a 12-month follow-up study. Crit Care. 2013;17(3):R100.

9. Herridge MS, Tansey CM, Matte A, Tomlinson G, DiazGranados N, Cooper A, et al. Functional disability 5 years after acute respiratory distress syndrome. N Engl J. 2011;364(14):1293-304.

10. Bienvenu JO, Colantuoni E, Mendez-Tellez PA, Dinglas VD, Shanholtz C, Husain N, et al. Depressive Symptoms and Impaired Physical Function after Acute Lung Injury: A 2-Year Longitudinal Study. Am J Respir Crit Care Med. 2012;185(5):517-24. 
11. Parry SM, Denehy L, Beach LJ, Berney S, Williamson HC, Granger CL. Functional outcomes in ICU - what should we be using? - an observational study. Crit Care. 2015;19(1):127.

12. Camara FM, Gerez AG, Miranda MLJ, Velardi M. Capacidade funcional do idoso: formas de avaliação e tendências. Acta Fisiatr. 2008;15(4):249-56.

13. Christakou A, Papadopoulos E, Patsaki I, Sidiras G, Nanas S. Functional Assessment Scales in a General Intensive Care Unit. A Review. Hospital Chronicles. 2013;8(4):164-70.

14. Ganong LH. Integrative reviews of nursing research. Res Nurs health. 1987;10 (1):1-11.

15. Vesz PS, Costanzi M, Stolnik D, Dietrich C, Freitas KLC, Silva LA, et al. Aspectos funcionais e psicológicos imediatamente após alta da unidade de terapia intensiva: coorte prospectiva. Rev Bras Ter Intensiva. 2013;25(3):218-24.

16. Haas JS, Teixeira C, Cabral CR, Fleig AHD, Freitas APR, Treptow EC, et al. Factors influencing physical functional status in intensive care unit survivors two years after discharge. BMC Anesthesiol. 2013;18(13):11.

17. Cabral CR, Teixeira C, Oliveira RP, Hass JS, Azzolins JS. Avaliação da mortalidade e qualidade de vida dois anos após a alta do CTI: dados preliminares de uma coorte prospectiva. Rev Bras Ter Intensiva. 2009;21(1):18-24.

18. Teixeira C, Cabral CR, Hass SJ, Oliveira RP, Vargas MAO, Freitas APR, et al. Exacerbação aguda da DPOC: mortalidade e estado funcional dois anos após a alta da UTI. J Bras Pneumol. 2011;37(3):334-40.

19. Garcia NG, Pereira MD, Silva BAK, Reis FA. Avaliação da independência funcional de pacientes pós-internados em unidade de terapia intensiva. ConScientiae Saude. 2012;11(2):296-304.

20. Curzel J, Forgiarini LA, Rieder MM. Avaliação da independência funcional após a alta da unidade de terapia intensiva. Rev Bras Ter Intensiva. 2013;25(2):9-98.

21. Azevedo LCP, Caruso P, Silva UVA, Torelly AP, Silva E, Rezense E, et al. Outcomes for patients with cancer admitted to the ICU requiring ventilatory support: results from a prospective multicenter study. CHEST. 2014;146(2):257-66.
22. Soares M, Caruso P, Silva E, Teles JMM, Lobo SMA, Friedman G, et al. Characteristics and outcomes of patients with cancer requiring admission to intensive care units: a prospective multicenter study. Crit Care Med. 2010;38(1):9-15.

23. Reis HSC, Almeida MLO, Silva MF, Rocha MS. A falência da extubação influencia desfechos clínicos e funcionais em pacientes com traumatismo cranioencefálico. J Bras Pneumol. 2013;39(3):330-8.

24. Murakami MF, Yamaguti WP, Onoue MA, Mendes JM, Pedrosa RS, Maida ALV. Evolução funcional de pacientes graves submetidos a um protocolo de reabilitação precoce. Rev Bras Ter Intensiva. 2015;27(2):161-9.

25. Hayes J, Black N, Jenkinson C, Young JD, Rowan KM, Daly K, et al. Outcome measures for adult critical care: a systematic review. Health Technol Assess. 2000;4(24):1-111.

26. Ribeiro M, Miyazaki MH, Jorge Filho D, Sakamoto H, Battistella LR. Reprodutibilidade da versão brasileira da Medida de Independência Funcional. Acta Fisiatrica. 2001;8(1):45-52.

27. Graf C. The Lawton-Instrumental Activities of Daily Living Scale. Am J Nurs. 2008;108(4):52-62.

28. Jennett B, Bond M. Assessment of outcome after severe brain damage. Lancet. 1975;1(7905):480-4.

29. Guimarães RB, Guimarães RB. Validação e adaptação cultural para a língua portuguesa de escalas de avaliação funcional em doenças cerebrovasculares: uma tentativa de padronização emelhora da qualidade de vida. Rev Bras Neurol. 2004;40(3):5-13.

30. Stiller K. Physiotherapy in intensive care: an updated systematic review. Chest. 2013;144(3):825-47.

31. Ambrosino N, Janahc N, Vaghegginia G. Physiotherapy in critically ill patients. Rev Port Pneumol. 2011;17(6):283-8.

32. De Jonghe B, Lacherade JC, Sharshar T, Outin H. Intensive care unit-acquired weakness: Risk factors and prevention. Crit Care Med. 2009;37(10):309-15.

33. Needham DM, Korupolu R, Zanni JM, Pradhan P, Colantuoni E, Palmer JB, et al. Early physical medicine and rehabilitation for patients with acute respiratory failure: a quality improvement project. Arch Phys Med Rehabil. 2010;91(4):536-42. 
34. Hodgson DL, Stiller K, Needham DM, Tipping CJ, Harrold $\mathrm{M}$, Baldwin CE, et al. Expert consensus and recommendations on safety criteria for active mobilization of mechanically ventilated critically ill adults. Crit Care. 2014;18(6):658.

35. Ydemann M, Eddelien HS, Lauritsen AO. Treatment of critical illness polyneuropathy and/or myopathy - a systematic review. Dan Med J. 2012;59(10):A4511.

36. Karnofsky DA, Burchenal JH. The clinical evaluation of chemotherapeutic agents in cancer. In: MacLeod CM (editor). Evaluation of chemotherapeutic agents. New York: Columbia University Press; 1949. p.191-205.

37. Mahoney FI, Barthel DW. Functional Evaluation: The Barthel Index. Md State Med J. 1965;14:61-5.

38. Granger CV, Hamilton BB, Keith RA, Zielezny M, Sherwin FS. Advances in functional assessment for medical rehabilitation. Topics Geriatr Rehabil. 1986;1(3):59-74.

39. Oken MM, Creech RH, Tormey DC, Horton J, Davis TE, McFadden ET, et al. Toxicity and response criteria of the Eastern Cooperative Oncology Group. Am J Clin Oncol. 1982;5(6):649-55.

40. Lawton MP, Brody EM. Assessment of older people: selfmaintaining and instrumental activities of daily living. Gerontologist. 1969;9(3):179-86.

Received in 01/29/2016

Recebido em 29/01/2016

Approved in 03/08/2016

Aprovado em 08/03/2016 
